\title{
Portuguese Agriculture in Transition
}





\section{Portuguese Agriculture in Transition}

Scott R. Pearson - Francisco Avillez

Jeffery W. Bentley • Timothy J. Finan

Roger Fox • Timothy Josling • Mark Langworthy

Eric Monke - Stefan Tangermann

CORNELL UNIVERSITY PRESS

Ithaca and London 
Copyright $(\mathcal{C} 1987$ by Cornell University

All rights reserved. Except for brief quotations in a review, this book, or parts thereof, must not be reproduced in any form without permission in writing from the publisher. For information, address Cornell University Press, 124 Roberts Place, Ithaca, New York 14850.

First published 1987 by Cornell University Press.

International Standard Book Number o-8014-1954-9

Library of Congress Catalog Card Number 86-29198

Librarians: Library of Congress cataloging information appears on the last page of the book.

The paper in this book is acid-free and meets the guidelines for permanence and durability of the Committee on Production Guidelines for Book Longevity of the Council on Library Resources. 